内田 育恵

杉浦 彩子

安藤富士子*

下方 浩史*

吉岡 真弓**

中島務**

国立長寿医療センター 耳鼻咽喉科

*国立長寿医療センター 疫学研究部

**名古屋大学大学院医学系研究科 頭頸部 - 感覚器外科学

耳鼻咽喉科

\section{補聴器所有に関連する要因および聴力の自他覚評価 についての検討}

一般地域住民を対象とした自記式質問票と聴力検査をもとに，年齢， 4 周波数 平均聴力レベル, 学歴, 難聴の自覚および他覚（他人から難聴を指摘されたこと があるか否か)，等の12項目と補聴器所有の有無との関係について，ステップワ イズ重回帰分析を用いて検討した。さらに難聴の自覚および他覚と平均聴力レベ ルとの関係についてもあわせて検討した．対象は40歳から84歳（平均年齢59.9 歳）の2,355名（男性1, 192名，女性1,163名）であった.

結果は, 男性では年歯令, 良聴耳聴力レベル, 不良聴耳聴力レベル, 学歴が, 女 性では年齢, 良聴耳聴力レベル，難聴の他覚が，補聴器所有の有無に有意に関係 していた。 また，男女ともに補聴器所有に対する年齢の影響は高齢になるほどむ しろ「負の効果」を示した。

一方，難聴の自覚および他覚と平均聴力レベルとの関係についての検討では, 両耳とも平均聴力レベルが正常もしくは軽度難聴であっても，自分で聞こえにく いと感じたり他人から難聴を指摘されたりしている場合があることが判明した。

今後さらに難聴の自覚および他覚における周辺雑音等の条件や, 各対象の語音 弁別能などについても検討する必要はあるが, 平均聴力レベルが正常もしくは軽 度難聴であっても，何らかの補聴を必要とする症例が潜在している可能性がある と考えられた。

キーワード : 補聴器, 難聴, 良聴耳聴力レベル, 不良聴耳聴力レベル

\section{はじめに}

補聴器を何台も所持しながら，過去に一度も耳鼻咽喉 科を受診したことがない聴力障害者にしばしば遭遇す る. 未だ耳鼻咽喉科医が関与していない補聴器流通の方 が圧倒的に多いのが現状である．全日本難聴者・中途失 聴者団体連合会のホームページを通じて, 補聴器を所有 する人を対象に 2003 年に実施された調査によると，高度

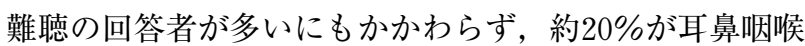
科医師による難聴の種類および程度に関する説明を受け ていないと回答し，医療とのかかわりなしで補聴器を購 入している現実が報告された1).

補聴器所有という事象を, 難聴によるコミュニケーシ ヨン障害への対策を求めた行動であると解釈し, 一般地 域住民における補聴器所有者の背景を検討した。また， 自分で聞こえが悪いと感じたり，人から聞こえが悪いと 指摘される聴力レベルはどのような範囲に分布するかに ついても年齢別に検討を加え, 補聴のニーズに関して考 察した.

\section{対象および方法}

国立長寿医療センター疫学研究部にて行っている『老 化に関する長期縦断疫学研究 (NILS-LSA)』第 3 次調査 に，2002年 5 月から 2004 年 5 月までの間に参加した40歳 から84歳までの一般地域住民男女 2,378 名の中で，今回 の解析に必要なすべての調查項目（質問票への有効回答 や聴力検査結果）が揃っている2,355名を対象とした。

NILS-LSA は老化の過程の経時的観察を目的として， 1997年10月に始動した調査研究で，血液検査，神経系検 査，呼吸機能検査，循環機能検査，視覚，聴覚，骨，形 態，体力，栄養，心理等，多部門の測定より成る包括的 研究である．地域住民から年齢・性別に層化した無作為 抽出を行って調查案内を送付した後，自由意志により説 明会に出席し，文書による説明と同意のもとに調査に参 加した者を対象としている，参加者は，測定日に先立ち 130以上の設問を含んだ自記式質問票を記入する．調査 の詳細については過去の報告を参照されたい23). 質問票 の中から今回解析に用いた変数は, (1)補聴器所有の有 
表 1 10歳毎の年齢群別対象数

\begin{tabular}{rcccccc}
\hline & $40-49$ 歳 & $50-59$ 歳 & $60-69$ 歳 & $70-79$ 歳 & 80歳以上 & 計 \\
\hline 男性 & 260 & 328 & 297 & 265 & 42 & 1,192 \\
女性 & 290 & 284 & 284 & 271 & 34 & 1,163 \\
\hline
\end{tabular}

表 2 補聴器所有の有無別にみた対象特性（平均值士標準偏差）

*は補聴器所有群と非所有群の間の $\mathrm{t}$ 検定による有意差を表す。 $(\mathrm{p}<0.05)$

\begin{tabular}{|c|c|c|c|c|}
\hline & \multicolumn{2}{|c|}{ 男性 } & \multicolumn{2}{|c|}{ 女性 } \\
\hline & 補聴器所有群 & 補聴器非所有群 & 聴器所有群 & 補聴器非所有群 \\
\hline $\mathrm{N}$ & 52 & 1,140 & 14 & 1,149 \\
\hline 年齢（歳） & $73.7 \pm 6.7^{*}$ & $59.4 \pm 11.5$ & $76.1 \pm 5.2^{*}$ & $59.5 \pm 11.9$ \\
\hline 良聴耳レベル（dB） & $53.6 \pm 15.0^{*}$ & $19.8 \pm 11.1$ & $50.2 \pm 13.3^{*}$ & $16.7 \pm 10.5$ \\
\hline 不良聴耳レベル（dB） & $63.3 \pm 18.0^{*}$ & $24.8 \pm 14.2$ & $59.4 \pm 19.9^{*}$ & $22.2 \pm 15.6$ \\
\hline
\end{tabular}

無，(2)難聴の自覚，(3)難聴の他覚，(4)就業の有無，5世 帯年収，(6)経済状態に満足しているか否か，7)学歴 2 分 類，8同居家族の有無，9おしゃべりの頻度，(10)外出の 頻度である．補聴器については，「よく使用している」, 「時々使用している」，「持っているが使用していない」 の回答群をまとめて ‘補聴器所有群”とした、難聴の自 覚については，過去の報告にあるように ${ }^{4)}\lceil$ 自分で聞こ えが悪いと思う」，「たまに思う」，の回答群をまとめて ‘難聴の自覚あり’ とした。難聴の他覚は，「人から聞こ えが悪いと言われたことがありますか」という設問に対 し，「よくある」，「たまにある」と答えた回答群を合算 して ‘難聴の他覚あり’ とした。世帯年収は 650 万円を 境に 2 分類とし，学歴については，高校までの群とそれ 以上の群の 2 分類，おしゃべりの頻度は友人や近所の人 と 1 週間に 1 回以上話すかどうかで 2 分類, 外出（買い 物，通院なども含む）頻度は $2-3$ 日に 1 回未満と以上 の 2 分類とした.

標準純音聴力検査はリオン社製 $\mathrm{AA}-73 \mathrm{~A}$ を使用して防 音室内で測定し， $0.5 ， 1,2,4 \mathrm{kHz}$ の 4 周波数平均気導 聴力を連続変数として解析に用いた.

対象特性に関して，補聴器所有群と非所有群の間での 比較は $\mathrm{t}$ 検定で解析した。 また本研究対象の聴力特性に ついては，難聴に関する 2 つ条件を用いて難聴者割合 と補聴器所有率を表した。難聴を定義する際の基準は必 ずしも統一されていないが5) 8)，過去の報告で多く用い られている条件として $0.5,1,2,4 \mathrm{kHz}$ の平均聴力レ ベルが $25 \mathrm{~dB}$ を超える者，とりわけ補聴器の候補者にな りうるという観点から，良聴耳の聴力レベルが $25 \mathrm{~dB}$ を 超えるという基準と, 良聴耳が中等度難聴以上という, 臨床的に補聴器の適応を考えることが多い難聴者群とし
て，0.5，1，2，4kHz の良聴耳平均聴力レベルが $40 \mathrm{~dB}$ を超えるという基準の 2 つについて対象を分類した.

解析については, 検討 1 ：補聴器所有に寄与する要因 の検索と, 検討 2 : 難聴の自覚他覚と良聴耳および不良 聴耳聴力レベルの関連について，の 2 課題を検討した。

検討 1 の統計学的解析には, Statistical Analysis System (SAS) version 8.2 を用い, 男女別に補聴器所有の有無 を目的変数としてまずステップワイズ重回帰分析を行 い，有意水準 $5 \%$ で採択された変数のみを用いて重回帰 分析を行い，各変数の標準化偏回帰係数を算出した．ス テップワイズ重回州分析を行った際の独立変数は，年 齢， $0.5 ， 1 ， 2 ， 4 \mathrm{kHz}$ の平均聴力レベルでみた良聴耳， 不良聴耳聴力レベルに加え，質問票の(1)から(10)回答の 計12変数である．検討 2 については，自分で聞こえが悪 いと感じたり，人から聞こえが悪いと指摘される聴力レ ベルはどのような範囲に分布するかを見るため，良聴 耳, 不良聴耳聴力レベル分布を回答別に散布図で表し, 年齢により比較した.

\section{結 果}

表 1 に対象者の性別, 年齢別分布を, 表 2 に補聴器所 有の有無別の対象特性を示す。男性1,192名，女性1, 163 名で，10歳ごとの各年齢群の対象数は40歳代から70歳代 までは男女それぞれ250名以上, 80歳以上では男性42名, 女性34名であった，対象の平均年齢は59.9 11 .8歳（男 性平均： $60.1 \pm 11.7$ 歳，女性平均： $59.7 \pm 11.9$ 歳）であ った。補聴器所有群は男女ともに，非所有群に比べて有 意に年齢が高く，良聴耳，不良聴耳聴力レベルとも有意 に悪かった。

良聴耳平均聴力レベルが $25 \mathrm{~dB}$ を超える難聴者につい 

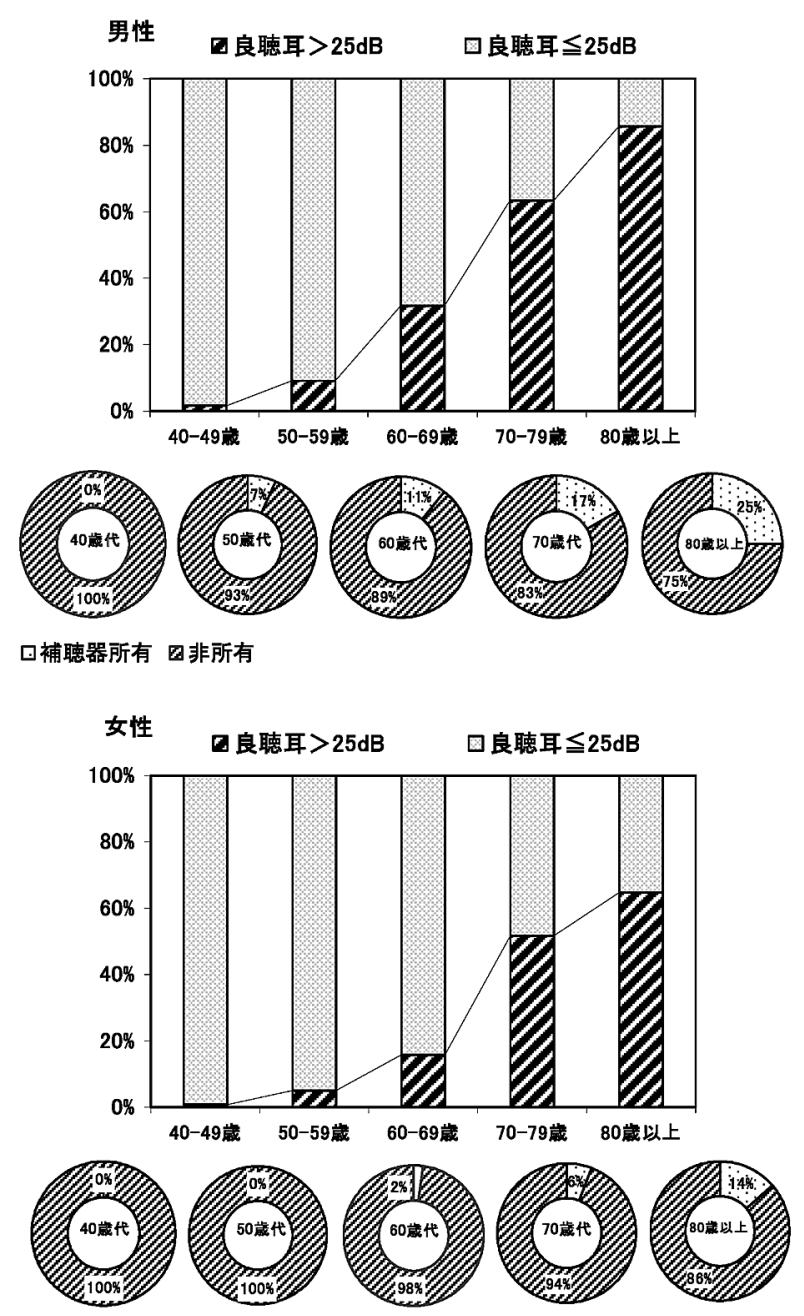

曰補聴器所有 口非所有

図 1 年齢群別の良聴耳聴力レベルが $25 \mathrm{~dB}$ を超える 難聴者割合と, 難聴者の補聴器所有の有無

ては，年代別に，男性では40歳代，50歳代，60歳代，70 歳代, 80 歳以上の順に，4名 (1.5\%)，30名 (9.1\%), 94 名 $(31.6 \%), 168$ 名 $(63.4 \%), 36$ 名 $(85.7 \%)$ であり, 男性全体では332名（27.9\%）であった（図 1).女性で は40歳代，50歳代，60歳代，70歳代，80歳以上の順に, 2 名 $(0.7 \%) ， 14$ 名 $(4.9 \%), 45$ 名 $(15.8 \%), 140$ 名 $(51.7 \%) ， 22$ 名 $(64.7 \%)$ で，女性全体では223名 (19.2\%) であり，この定義による難聴者の対象全体に おける割合は $23.6 \%$ あった。良聴耳聴力レベルが $25 \mathrm{~dB}$ を超える難聴者のうち, 補聴器所有者の割合を 図 1 の円グラフに示した. 10歳ごとの年齢群別にみた補 聴器所有者の人数は, 男性では40歳代，50歳代，60歳 代, 70歳代, 80歳以上の順に，0名 (0\%), 2 名 (6.7\%), 10名 $(10.6 \%), 28$ 名 $(16.7 \%), 9$ 名 $(25.0 \%)$ であり, 女性は0名 $(0 \%), 0$ 名 $(0 \%), 1$ 名 $(2.2 \%), 8$ 名 $(5.7 \%), 3$ 名 $(13.6 \%)$ であった。難聴者の補聴器所

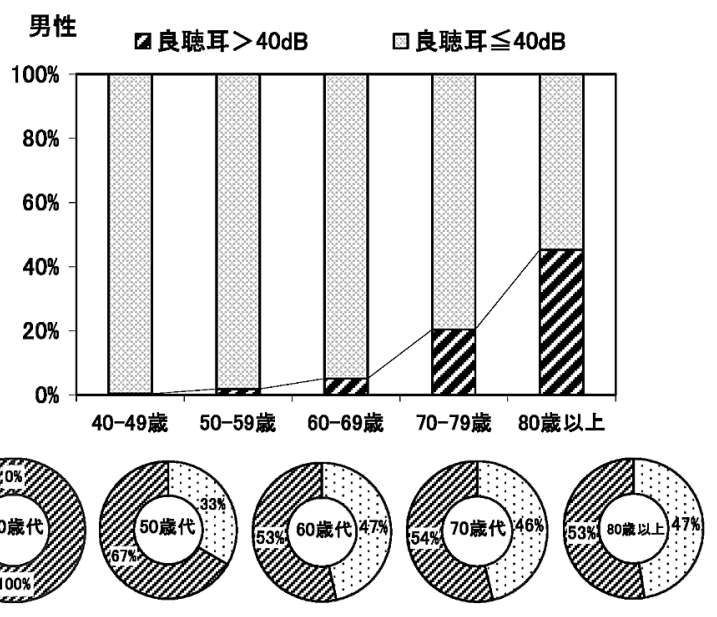

口補聴器所有 口非所有

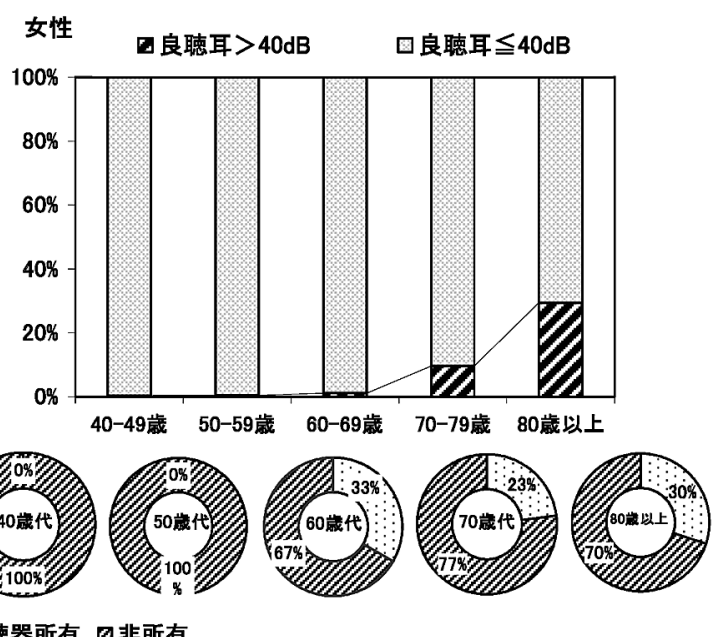

図 2 年齢群別の良聴耳聴力レベルが $40 \mathrm{~dB}$ を超える 難聴者割合と，難聴者の補聴器所有の有無

有率は, 男性では $14.8 \%$, 女性 $5.4 \%$, 男女合わせた全 体では $11.0 \%$ あった。

次に良聴耳平均聴力レベルが $40 \mathrm{~dB}$ を超えるという条 件で定義した場合, 年代別の難聴者は, 男性では40歳 代，50歳代，60歳代，70歳代，80歳以上の順に，1名 $(0.4 \%), 6$ 名 $(1.8 \%), 15$ 名 $(5.1 \%), 54$ 名 $(20.4 \%)$ ， 19名 $(45.2 \%)$ であり，女性は 1 名 $(0.3 \%), 1$ 名 $(0.4 \%)$ ， 3 名 $(1.1 \%) ， 26$ 名 $(9.6 \%) ， 10$ 名 $(29.4 \%)$ であった (図 2 )。この定義による難聴者は，男性全体では95名 $(8.0 \%)$ ，女性全体では41名 $(3.5 \%)$, 対象全体におけ る割合は $5.8 \%$ あった。この難聴者群における補聴器 所有率は，男性では $45.3 \%$ ，女性 $24.4 \%$ ，男女合わせた 全体では $39.0 \%$ あった (図 2 の円グラフ).10歳ごと の年齢群別にみた補聴器所有者の人数は, 男性では40歳 代，50歳代，60歳代，70歳代，80歳以上の順に，0名 ( $0 \%), 2$ 名 $(33.3 \%), 7$ 名 $(46.7 \%), 25$ 名 (46.3\%)， 
表 3 補聴器所有の有無に寄与する要因検索の結果 目的変数：補聴器所有の有無

独立変数：年齢， 4 周波数平均聴力の良聴耳レ ベル，同不良聴耳レベル，難聴自 覚，難聴他覚，就業の有無，世帯年 収, 経済状態満足度, 学歴, 同居家 族，おしゃべりの頻度，外出の頻度

\begin{tabular}{|c|c|c|c|}
\hline \multirow{6}{*}{ 男 } & 有意な独立変数 & 標準化偏回帰係数 & $\mathrm{p}$ 值 \\
\hline & 年齢 & -0.002 & 0.0002 \\
\hline & 良聴耳レベル & 0.008 & $<0.0001$ \\
\hline & 不良聴耳レベル & 0.001 & 0.029 \\
\hline & 学歴（ 2 分類） & 0.025 & 0.024 \\
\hline & モデル全体の決定係数 & 0.28 & \\
\hline \multirow{5}{*}{ 女 } & 有意な独立変数 & 標準化偏回帰係数 & $\mathrm{p}$ 值 \\
\hline & 年齢 & -0.0007 & 0.025 \\
\hline & 良聴耳レベル & 0.003 & $<0.0001$ \\
\hline & 難聴他覚（2 分類） & 0.016 & 0.032 \\
\hline & モデル全体の決定係数 & 0.11 & \\
\hline
\end{tabular}

9 名 $(47.4 \%)$ であり，女性は 0 名（０\%)，0名（0\%)， 1 名 $(33.3 \%), 6$ 名 $(23.1 \%), 3$ 名 $(30.0 \%)$ であった。

検討 1 : 補聴器所有の有無に寄与する要因検索の結果 を，表 3 に示す．ステップワイズ重回帰分析にて有意な 要因として採択されたのは，男性では年齢，良聴耳聴力 レベル，不良聴耳聴力レベル，学歴の 4 要因で，年齢は 補聴器の所有に関して負の効果（すなわち年齢が高くな るほど補聴器を所有しない傾向）を示し，その他の要因

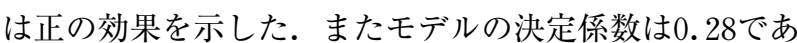
り，この 4 要因によって補聴器所有の有無を説明できる

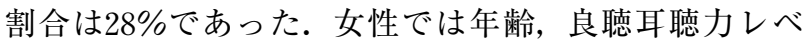
ル，難聴の他覚の 3 要因が有意であった．年齢は弱いな がらも負の効果を，良聴耳聴力レベルと難聴の他覚は正 の効果を示したが，この 3 要因で補聴器所有の有無を説 明できる割合は $11 \% に$ 過ぎなかった。

検討 $2 ： 40$ 歳代と70歳代の男性の 2 群について，難聴 の自覚他覚と良聴耳および不良聴耳聴力レベルとの関係 を図 3 に示す。 40歳代，70歳代ともに，両耳の聴力レベ ルが 40dB 以内の領域では，“難聴の自覚他覚ともにな し’，“自覚あり他覚なし’，“自覚なし他覚あり’，“自覚 他覚ともにあり’の 4 種のマーカーすべてが，同程度の 聴力レベルの領域に混在していた。40歳代男性では良聴 耳，不良聴耳レベルともに $40 \mathrm{~dB}$ 以内におさまる例がほ とんどで，いずれかの耳の聴力レベルが $40 \mathrm{~dB}$ を超えて
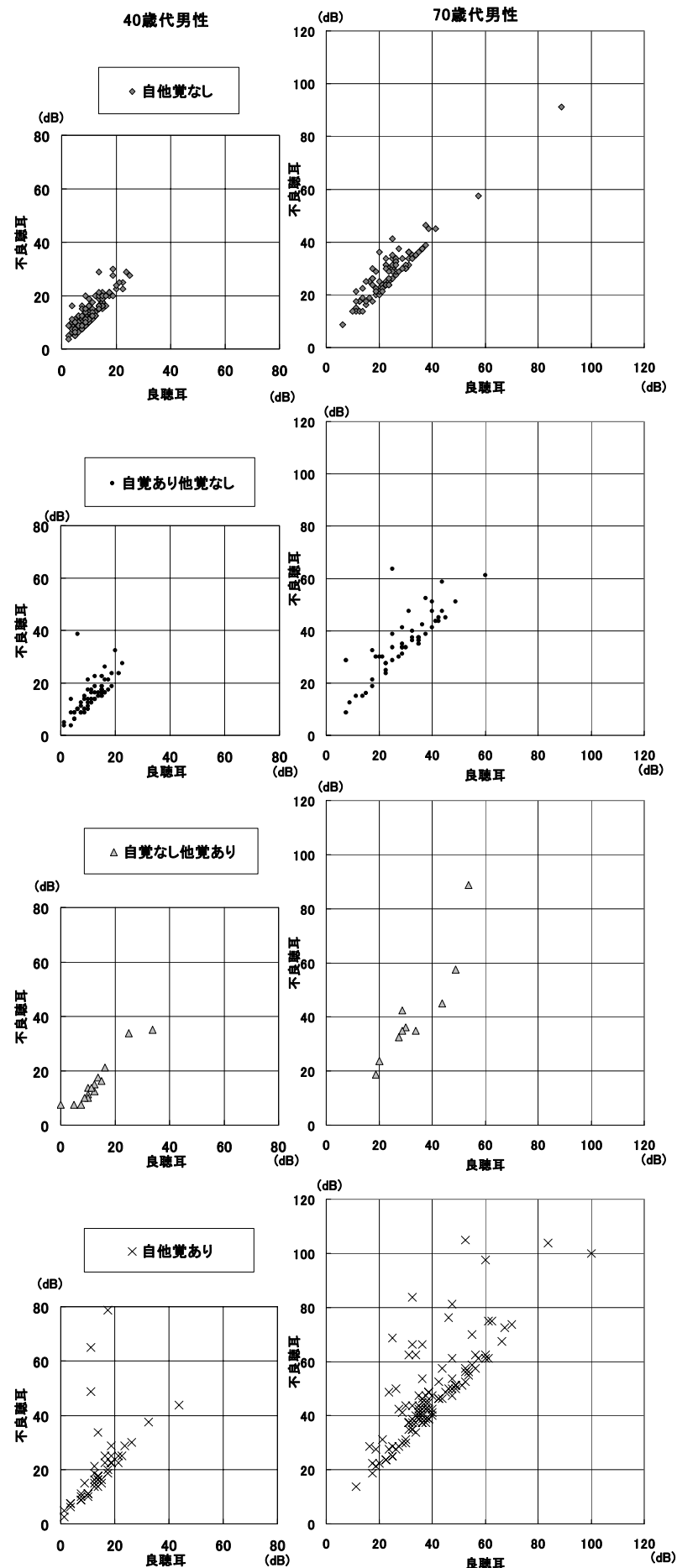

図 3 難聴の自覚，他覚と，良聴耳および不良聴耳聴力 レベル

いる例はすべて ‘難聴の自覚他覚ともにあり’の回答者 である。一般に正常範囲と考えられる両耳とも $20 \mathrm{~dB}$ 以 内の領域に注目すると，40歳代では 4 種のマーカーすべ てが観察される。一方70歳代男性では，全体に聴力レベ ルの分布のバラツキが大きくなり, “自覚他覚ともにあ り’の回答マーカーの数が増える. $20 \mathrm{~dB}$ 以内の領域に 
属する例は少なくなり，20dB 以内に属しながら 自覚 他覚ともにあり'と答えた例は非常に少なかった。また 良聴耳レベルが $40 \mathrm{~dB}$ を超える領域であっても，4種の 回答マーカーすべてが出現している. 他の年齢群の散布 図は提示していないが，10歳毎に分布のバラツキが広が る傾向を示し，女性では，聴力レベル分布のバラツキが 男性に比べて少なくなっているが概ね同様の傾向を示し た.

\section{考察}

一般地域住民対象の難聴者割合とその補聴器保有率 を, 過去の疫学調査と比較すると, 米国ウイスコンシン 州の Epidemiology of Hearing Loss Study ${ }^{910)}$ では, 0.5, $1,2,4 \mathrm{kHz}$ の平均聴力レベルで不良聴耳が $25 \mathrm{~dB}$ を超 える難聴者の割合は，対象 3,753 名（平均年齢65.8歳） のうち $45.9 \%$ で，過去に補聴器を所有したことがあるの はその難聴者のうち $20.7 \%$ あ゙あたと報告されている. 米国マサチューセッツ州の Framingham Cohortでは, $0.5,1,2,3 \mathrm{kHz}$ の平均聴力レベルで良聴耳が $26 \mathrm{~dB}$ を 超える難聴者の割合は，1,662名（平均年齢73歳）の対 象の $42 \%$ で，171名が補聴器を使用したことがあったと 報告された ${ }^{11)}$. 公的健康保険で補聴器費用の一部が補助 されるオランダでは, 補聴器保有は, 聴力障害で耳鼻咽 喉科医を受診した患者の $20 \%$ と報告された ${ }^{6}$. 本研究コ ホートでは，2,355名（平均年齢59.9歳）の対象のうち, 4 周波数平均の良聴耳聴力レベルが $25 \mathrm{~dB}$ を超える難聴

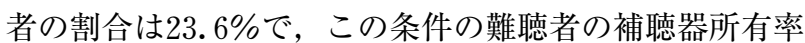
は11.0\%であった，過去の報告と，調查対象の年齢分布 や難聴を定義する条件が違うため同列に論ずることはで きないが，上記の報告における調查が1980年代から1990 年代に行われていることを考慮に入れると，本コホート において, 補聴器の有効性が期待できる対象者が補聴器 を所有している割合はかなり低いと考えられた.

補聴器所有に寄与する要因を検索すると，男女ともに 良聴耳聴力レベルが入っていたことは，各々の聴力障害 の程度を表す指標であるためもっともであるが，年齢に ついては，聴力レベルで調整してしまうと男女ともに補 聴器の所有に関して負の効果，すなわち年齢が高くなる ほど補聴器を所有しない傾向を示した．以前より同等の 聴力障害レベルで比較した場合，高齢になるほど自己の 障害を認識しにくくなることが指摘されている ${ }^{8122}$. ま た同等の聴力レベルや年齢では，補聴器使用経験のある 者の方が，WHO の国際生活機能分類（ICF ${ }^{13}$ に示され る「活動の制限」や「参加の制約」に関して, 補聴器使 用経験のない者より強く認識していることも報告されて いる ${ }^{14)}$. 今回の解析結果から，高齢という要素により,
難聴によって生じる自己の不利益の認識がそしくなり， 補聴器の取得にいたらないという結果に結びつく可能性 が推測された，過去の報告では，聴力レベルや語音聴取 能のほかに，難聴の受容，補聴器関連コストへの心配， 収入満足度，パーソナリティー，所得，教育レベル，社 会的支援の得やすさ，健康状態，手先の器用さなどが補 聴器使用を左右する要因であるとされている ${ }^{1516177)}$. 本 研究では, 就業の有無や経済状態，同居家族については 男女ともに有意な影響は示さなかった。補聴器使用に影 響する要因には性差も指摘されており，本研究では男性 で学歷が高い方が補聴器を所有する率が高く，女性で人 から難聴を指摘されることが補聴器の所有に正の効果を 示した，人との交際や子育てといった，伝統的に女性の 領域とされてきた活動には，効果的なコミュニケーショ ン能力が求められる．難聴によってこれらの活動に支障 を来すと，女性ではセルフイメージに，男性より大きな 負の影響が及ぶという報告がある ${ }^{18}$ 。また同等の聴力障 害の場合，男性より進んで救済を求める傾向があるとの 報告があるが19)，本コホートにおいては明らかでなかっ た.

検討 2 では， 4 周波数平均聴力レベルで良聴耳も不良 聴耳も正常か軽度難聴に属する場合でも，自分で聞こえ にくいと感じたり人から指摘されたりしているケースが 少なくないことが示された。しかし本研究では，残念な がら語音聴力検査は調査項目に含まれていないため，今 回の検討で難聴の自覚, 他覚がある対象群の語音弁別能 が相対的に不良である可能性も否定できない。聞こえに くさの自覚や他覚には純音聴力検査結果だけからは評価 できない機能である語音弁別能や劣化した聴取環境にお ける聞き取り能力なども，関与しているであろう．特に 背景雑音の存在下では，感音難聴者では健聴者に比べて より多くの信号情報を必要とすることが知られてい $る^{200}$. 純音聴力検査は聴力障害の定量的な情報をもたら すものの，個人の日常生活における障害の影響を必ずし も反映しないことが過去の報告においても指摘されてい る . 純音聴力検查上の難聴が軽度であっても，かなり の障害を感じている場合もある ${ }^{21)}$. 一方補聴器相談の現 場では，まず相談者の聴力閾值を基に装用による閾值低 下を目標にする場合が多く，聞こえにくいと感じ始めた 早期の相談者や軽度難聴者に対して, 純音聴力検査結果 をもとに補聴器の適応にならないと説明されている症例 にも遭遇する，本検討結果から，純音聴力検査の平均聴 カレベルは聞こえにくさの一側面を表すに過ぎず，たと え正常に属する場合でも難聴の自覚他覚が存在すること が示された.すなわち聞こえにくさの問題解決のために は，補聴による閾值改善以外の要素，例えばデジタル信 
号処理の騒音抑制や指向性マイクの機能によってもたら される $\mathrm{S} / \mathrm{N}$ 比の改善のみで有効な場合もあるのではな いかと考えられた，軽度難聴者では，静かな環境におけ る裸耳䦨值と装用閾值が同じであっても, 補聴機器の需 要があり得るのではないかと推測される。しかし現時点 では，費用対効果や聴覚障害者に対する製品であるとい うイメージの点から, 最新のデジタル信号処理機能を備 えた補聴器が軽度難聴者に活用されることは少ない。近 年, 免許・資格が不要の ‘特定小電力無線’ は, 近距離 間での簡易連絡用コミュニケーション手段として健聴 者, 難聴者問わず，一般社会に広く活用され始めてい る. 一例としてイヤホンガイドは，観光地や大きな声が 出せない美術館でのツアー, 騒音の多い工場見学などの ガイド等で用いられ，環境騒音を遮断して話者の音声を 聴取することができ，イヤホン使用者がボリウム調整で きるため，使用者の差異を問わず利用されている．この ような機器使用に対する社会的な負の印象や抵抗はない ことから, 早期の聴覚障害者にとって補聴が円滑に受容 されるためにも，健聴者と難聴者の間に境界なく適応す る聴覚支援機器の出現が期待される.

\section{ま と め}

1.一般地域住民を対象にした調查から，質問票と純 音聴力検査の結果をもとに，1）補聴器所有に寄与する 要因の検索と，2）難聴の自覚他覚と良聴耳および不良 聴耳聴力レベルの関連について検討した。

2. 男性では年齢, 良聴耳聴力レベル，不良聴耳聴力 レベル，学歴が，女性では年齢，良聴耳聴力レベル，難 聴の他覚が, 補聴器の所有に有意な効果を示した. 年齢 は，男女ともに高齢になるほど補聴器所有に対して負の 効果を示した。

3. 4 周波数平均聴力レベルで両耳とも正常か軽度難 聴に属する場合でも，自分で聞こえにくいと感じたり人 から指摘されているケースがあり，何らかの補聴を必要 とする症例が潜在している可能性があると考えられた。

\section{参考文献}

1）補聴器供給システムの在り方研究会（代表：河野康徳）： 補聴器流通に関する意識調査について。補聴器供給シス テムの在り方に関する研究 3 年次報告書. 適正な補聴 器普及のための供給システムに関する調查研究; 2004 : 54-62頁.

2) Shimokata $\mathrm{H}$, Ando F, Niino $\mathrm{N}$ : A new comprehensive study on aging - the National Institute for Longevity Sciences, Longitudinal Study of Aging (NILS-LSA). J Epidemiol 2000 ; Suppl 10: 1-9.
3）内田育恵, 中田誠一, 植田広海, 中島 務, 新野直明 他：加齢および全身性基礎疾患の歪成分耳音響放射に及 ぼす影響. Otol Jpn 2004；14：154-159.

4) Bagai A, Thavendiranathan P, Detsky AS : Does this patient have hearing impairment? JAMA 2006; 295 : 416-428.

5) WHO Report of the Informal Working Group On Prevention Of Deafness And Hearing Impairment Programme Planning. Geneva, 1991.

6) Duijvestijn JA, Anteunis LJC, Hendriks JJT, Manni JJ : Definition of hearing impairment and its effect on prevalence figures. A survey among senior citizens. Acta Otolaryngol 1999; 119 : 420-423.

7) Sindhusake D, Mitchell P, Smith W, Golding M, Newall $\mathrm{P}$, et al: Validation of self-reported hearing loss. The Blue Mountains Hearing Study. Int J Epidemiol 2001; 30 : 1371-1378.

8) Uchida Y, Nakashima T, Ando F, Niino N, Shimokata H : Prevalence of self-perceived auditory problems and their relation to audiometric thresholds in a middle-aged to elderly population. Acta Otolaryngol $2003 ; 123$ : 618626.

9) Cruickshanks KJ, Wiley TL, Tweed TS, Klein BEK, Klein $\mathrm{R}$, et al: Prevalence of hearing loss in older adults in Beaver Dam, Wisconsin. The Epidemiology of Hearing Loss Study. Am J Epidemiol 1998; 148 : 879-886.

10) Popelka MM, Cruickshanks KJ, Wiley TL, Tweed TS, Klein BEK, et al: Low prevalence of hearing aid use among older adults with hearing loss: The Epidemiology of Hearing Loss Study. J Am Geriatr Soc 1998; 46 : 1075-1078.

11) Gates GA, Cooper JC Jr, Kannel WB, Miller NJ : Hearing in the elderly: the Framingham cohort, 1983-1985. Part I. Basic audiometric test results. Ear Hear 1990; 11: 247-256.

12) Gordon-Salant S, Lantz J, Fitzgibbons P : Age effects on measures of hearing disability. Ear Hear 1994; 15 : 262-265.

13) WHO. International Classification of Functioning, Disability and Health. Geneva: World Health Organization ; 2001.

14) Helvik AS, Jacobsen G, Wennberg S, Arnesen H, Ringdahl A, et al: Activity limitation and participation restriction in adults seeking hearng aid fitting and rehabilitation. Disability and Rehabilitation 2006 ; 28: 281-288.

15) Cox RM, Alexander GC, Gray GA: Who wants a hearing aid? Personality profiles of hearing aid seekers. Ear Hear $2005 ; 26 ; 12-26$. 
16) Garstecki DC, Erler SF : Hearing loss, control, and demographic factors influencing hearing aid use among older adults. J Speech Lang Hear Res 1998 ; 41 : 527537.

17) Humes LE, Wilson DL, Humes AC: Examination of differences between successful and unsuccessful elderly hearing aid candidates matched for age, hearing loss and gender. Int J Audiol 2003 ; 42 : 432-441.

18) Hetu R, Jones L, Getty L: The impact of acquired hearing impairment on intimate relationships: Implications for rehabilitation. Audiology 1993; 32 : 363-381.

19) Brunenberg DEM, Chenault MN, Anteunis LJC : Changing characteristics of first-time hearing aid applicants in The Netherlands in the past decade. Int J Audiol 2004; $43: 211-217$
20) Kim HH, Barrs DM : Hearing aids : A review of what's new. Otolaryngol Head Neck Surg 2006; 134 : 10431050.

21) Newman CW, Jacobson GP, Hug GA, Sandridge SA : Perceived hearing handicap of patients with unilateral or mild hearing loss. Ann Otol Rhinol Laryngol 1997; 106 : 210-214.

本論文の要旨は, 第107回日本耳鼻咽喉科学会総会・学術 講演会（東京）において口演した.

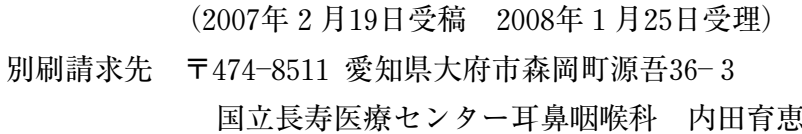

Analyses of Factors Contributing to Hearing Aids Use and Both Subjective and Objective Estimates of Hearing

Yasue Uchida, M.D., Ph.D., Saiko Sugiura, M.D., Ph.D., Fujiko Ando, M.D., Ph.D.*

Hiroshi Shimokata, M.D., Ph.D.*, Mayumi Yoshioka, M.D. ${ }^{* *}$ and Tsutomu Nakashima, M.D., Ph.D. ${ }^{* *}$

Department of Otorhinolaryngology, National Center for Geriatrics and Gerontology, Obu

${ }^{*}$ Department of Epidemiology, National Center for Geriatrics and Gerontology, Obu

${ }^{* *}$ Department of Otorhinolaryngology Cognitive and Speech Medicine, Nagoya University School of Medicine, Nagoya

The use of hearing aids, regardless actual implementation, may be interpreted as a cry for help in hearing difficulty. We assessed factors contributing to hearing aid possession and predicted needs of hearing assistance from the distribution of hearing level in self-estimated (subjective) hearing loss and hearing loss pointed out by others (objective) in a population-based aging cohort.

Of 1192 men and 1163 women aged 40 to 84 years, the prevalence of hearing loss using the criteria of a mean hearing threshold $>25 \mathrm{~dB}$ at frequencies of $0.5,1,2$, and $4 \mathrm{kHz}$ in the better ear was $23.6 \%$. Hearing aids were possessed by $11.0 \%$ in the hearing loss group. Statistical analysis by gender was done to identify factors associated with hearing aid possession using stepwise multiple regression in which independent variables were age, hearing in the better and worse ear, and items from response to a questionnaire on self-estimated hearing loss, hearing loss pointed out by others, job, household income, financial satisfaction, education, housemate, how often others were talked to and how often those surveyed went out. Age, better-ear hearing, worse-ear hearing, and education statistically influenced hearing aid possession in men, and age, better-ear hearing, and hearing loss pointed out by others statistically influenced women. Age had a negative effect on hearing aid possession in both men and women, indicating that possession decreased with aging.

Scattergrams were plotted with worse-ear hearing on the $\mathrm{y}$ axis and better-ear hearing on the $\mathrm{x}$ axis for 4 groups of respondents divided into groups with self-estimated hearing loss or hearing loss pointed out by others: (1) no subjective and objective hearing loss, (2) subjective but no objective hearing loss, (3) objective but no subjective hearing loss, and (4) both subjective and objective hearing loss. Many respondents had either subjective or objective or both subjective and objective hearing loss, even within $20 \mathrm{~dB}$ of hearing level of both ears in their $40 \mathrm{~s}$. These facts implied that early-stage candidates for hearing aids may not require threshold reduction, although aided thresholds were commonly used indicators in fitting.

Keywords : hearing aid, hearing loss, better-ear hearing, worse-ear hearing

Nippon Jibiinkoka Gakkai Kaiho (Tokyo) 111: 405-411, 2008 